\title{
PEMBENTUKAN ADMINISTRASI DUSUN SERTA PEMASARAN INDUSTRI MAKANAN DI DUSUN MANGIRAN BANTUL YOGYAKARTA
}

\section{ESTABLISHMENT OF VILLAGE ADMINISTRATION AND MARKETING OF FOOD INDUSTRY IN MANGIRAN VILLAGE BANTUL YOGYAKARTA}

\author{
B Gunawan ${ }^{1 a}$ \\ 'Universitas Muhammadiyah Yogyakarta, Jl Brawijaya Tamantirto Kasihan Bantul Yogyakarta \\ aKorespondensi:Barbara Gunawan; E-mail: Barbaragunawan@yahoo.co.id \\ (Diterima: 05-09-2019; Ditelaah: 06-09-2019; Disetujui: 17-04-2020)
}

\begin{abstract}
This service aims to develop an economically independent community and the formation of village administration. Partners in this program are residents and small businesses producing and selling coconut oil. The problem of the coconut oil industry is the marketing of Kethak, which is a waste of making coconut oil. The methods that will be used to achieve these objectives are 1) providing plastic packaging, 2) manufacturing brands, 3) procuring signposts, and 4) compiling population data. The results of this program are 1) the presence of attractive product packaging, 2) the presence of a brand, 3) the signposts of the industry, and 4) administrative data that is correct and organized, both in the form of soft files and frames.
\end{abstract}

Keywords: Administration, marketing, mangiran, kethak.

\begin{abstract}
ABSTRAK
Tujuan pengabdian ini adalah mengembangkan masyarakat yang mandiri secara ekonomi dan pembentukan administrasi dusun. Mitra dalam program ini adalah warga dan usaha kecil pembuatan dan penjualan minyak kelapa. Permasalahan industri minyak kelapa adalah tentang pemasaran Kethak yang merupakan ampas pembuatan minyak kelapa. Metode yang akan dipakai untuk mencapai tujuan tersebut adalah 1) penyediaan plastik kemasan, 2) pembuatan merk, 3) pengadaan plang papan nama, dan 4) penyusunan data kependudukan.

Hasil dari program ini adalah 1) adanya kemasan produk yang menarik, 2) adanya merk, 3) plang papan nama industri kethak, dan 4) data administrasi yang benar dan tertata, baik berupa soft file maupun bingkai.

Kata kunci: Administrasi, mangiran, pemasaran kethak.

Gunawan, B,. (2020). Pembentukan Administrasi Dusun Serta Pemasaran Industri Makanan di Dusun Mangiran Bandul Yogyakarta. Jurnal Qardhul Hasan : Media Pengabdian kepada Masyarakat, 6(1), 49-56.
\end{abstract}




\section{PENDAHULUAN}

Mangiran adalah salah satu dusun yang terdapat di Desa Trimurti, Kecamatan Srandakan, Kabupaten Bantul Daerah Istimewa Yogyakarta. Berdasarkan data yang tertera di Web Desa diperoleh informasi bahwa dusun Mangiran dihuni oleh sebanyak 433 KK, 12 RT, dan 1290 orang yang terbagi menjadi 642 warga berjenis kelamin pria, dan 648 warga berjenis kelamin wanita. Mayoritas pekerjaan warga adalah buruh tani dan berwirausaha, sedangkan mayoritas agama adalah Islam. Menurut Sesrita et al., (2017) kewirausahaan yaitu motivasi, akhlak, perilaku serta skill seseorang untuk menjalankan suatu usaha atau yang mengarahkan kepada pencarian, menciptakan serta mengaplikasikan tata cara dalam bekerja dalam basis iptek untuk membuat produk baru dalam meningkatkan efisiensi untuk mendapatkan laba. Sedangkan Usaha Mikro Kecil dan Menengah (UMKM) adalah kegiatan ekonomi rakyat yang berskala kecil dan memenuhi kriteria kekayaan bersih atau hasil penjualan tahunan serta kepemilikan sebagaimana diatur dalam Undang-undang (Mardiah et al., 2015). Dari 1290 warga, jenjang pendidikan terbanyak adalah SLTA dan tamat SD, masing-masing 27 persen. Hal ini menunjukkan bahwa tingkat pendidikan bukan menjadi syarat utama selagi ada kemauan dan terus berusaha. Tentunya peranan dari UMKM dalam menggerakan roda perekonomian masyarakat Desa Mangiran.

Potensi unggulan yang ada di Dusun Mangiran adalah industri pembuatan minyak kelapa. Dalam proses produksi minyak kelapa, terdapat ampas yang biasa disebut Kethak (gelondo). Tidak ada permasalahan dalam produksi dan pemasaran minyak kelapa, namun permasalahan adalah pada pemasaran kethak. Permasalahan yang dihadapi oleh Mitra untuk aspek pemasaran kethak adalah 1) Tidak ada merk, 2) Kemasan masih manual dan sangat sederhana, 3) Kesulitan dalam memasarkan produk, dan 4) Pasar yang sangat terbatas. Selama ini kethak hanya dikemas dengan cara dibungkus dan diikat menggunakan plastik. Apabila produk-produk hasil pertanian dan industry rumahan diolah dengan baik akan memiliki nilai jual yang tinggi, dengan begitu taraf ekonomi masyarakat akan meningkat (Paramita et al., 2018). Permasalahan berikutnya adalah tentang administrasi dusun. Permasalahan untuk administrasi dusun adalahbelum adanya data penduduk (status, pendidikan, pekerjaan) baik soft file maupun bingkai.

Tujuan program adalah untuk mengembangkan masyarakat yang mandiri secara ekonomi dan pembentukan administrasi dusun. Pelatihan pelaporan dan administrasi kependudukan berbasis Microsoft Excel diberikan kepada forum perangkat Desa Mangiran agar mereka mempunyai kemampuan dan keahlian dalam mengolah data administrasi kependudukan dan mampu melayani masyarakat Desa Mangiran dengan baik. Kegiatan pengabdian pada masyarakat ini merupakan Program KKN PPM yang diselenggarakan dengan melibatkan 10 mahasiswa.

Menurut Maimunah et al., (2018) masyarakat pada satu kondisi belum mampu menemukan cara untuk melepaskan dari kesulitan ekonomi mereka, harus ada pihak yang mengarahkan, atau memberikan informasi penting untuk memulai aktivitas ekonomi mereka bahkan yang mengarahkan mereka pada kegiatan ekonomi yang berkelanjutan hingga pada tahap pemasaran produk yang dihasilkan serta persaingan pasar. Sehingga tujuan pengabdian ini adalah untuk memberikan pendampingan dan pendidikan kepada masyarakat mengenai pembentukan administrasi dusun dan strategi pemasaran, khususnya dalam hal pengemasan dan merek produk. Dengan adanya pendampingan dan pendidikan tersebut diharapkan industri rumah tangga 
di Desa Mangiran dapat berkembang lebih luas.

\section{MATERI DAN METODE}

Metode yang digunakan adalah Participatory action research dengan pendekatan partisipatif melalui FGD's tokoh masyarakat, PKK, dan Mitra.

\section{Pemilihan khalayak sasaran}

Awalnya tim pengabdi melakukan observasi ke Dusun Mangiran Srandakan Bantul, kemudian Pengabdi melakukan wawancara dengan Lurah, Kepala Dusun, ketua PKK Dusun, dan warga. Berdasarkan wawancara dan diskusi diperoleh kesepakatan program berupa pembuatan administrasi dusun. Pengabdi juga melihat potensi yang ada di Dusun Mangiran berupa pembuatan minyak kelapa yang memang sudah dirintis sejak lama. Setelah melalui berbagai pertimbangan kelayakan, maka sasaran pada kegiatan pengabdian ini adalah para warga dan usaha pembuatan dan penjualan minyak goreng milik Kelompok Warga Dusun Mangiran, Desa Trimurti, Bantul DIY.

Langkah selanjutnya yang dilakukan pengabdi adalah mengidentifikasi masalah yang ada pada mitra. Masalah-masalah yang didapatkan pada mitra tersebut selanjutnya digolongkan dalam dua aspek permasalahan, yaitu aspek manajemen pemasaran dan administrasi dusun.

Langkah selanjutnya adalah memberikan tawaran solusi kepada mitra atas persoalan yang mereka alami. Langkah ini diharapkan dapat menjadi jalan keluar bagi mitra dalam menghadapi persoalan mereka selama ini.

Tahapan/langkah-langkah

dalam melaksanakan solusi dari permasalahan mitra: Industri makanan permasalahan: Tidak ada merk; tidak ada kemasan; kesulitan dalam memasarkan produk

Administrasi dusun permasalahan: Belum adanya plang papan nama untuk kantor Kepala Dusun; Belum ada data penduduk (usia, status, pendidikan, pekerjaan, dan lain-lain).
Metode pendekatan yang ditawarkan untuk menyelesaikan persoalan mitra: Metode pelaksanaan yang ditawarkan dalam bidang pemasaran produk; pelatihan manajemen pemasaran, merancang dan membuat merk, merancang dan membuat kemasan, metode pelaksanaan yang ditawarkan dalam bidang administrasi dusun, membuat plang papan nama untuk kepala dusun, membuat data penduduk (status, pendidikan, dan pekerjaan).

Partisipasi mitra terhadap program ini adalah mitra mencarikan informasi terkait peralatan yang dibutuhkan dan harga per itemnya. Informasi-informasi tersebut penting untuk menentukan besaran pengajuan anggaran. Disamping itu mitra dalam pelaksanaan program nantinya akan mengundang para UKM yang ada di wilayah sekitarnya untuk mengikuti pelatihan dan pendampingan manajemen pemasaran.

\section{HASIL DAN PEMBAHASAN}

\section{Penyusunan Administrasi Dusun}

Pembuatan administrasi Dusun Mangiran diawali dengan melakukan survey ke rumah-rumah penduduk Dusun Mangiran sambal meminta Kartu Keluarga (KK). Data pada Kartu Keluarga tidak jarang sebetulnya sudah tidak sesuai, misalnya karena adanya kematian atau kelahiran, bisa juga karena ada anak yang jenjang pendidikannya sudah berubah atau sudah lulus sekolah. Oleh karena itu pendataan tidak cukup hanya dengan melihat Kartu Keluarga saja, tapi juga melalui wawancara. Berdasarkan data yang terdapat di Kartu Keluarga (KK) dan hasil wawancara, maka tahap selanjutnya adalah melakukan tabulasi data menggunakan program Excell. Adapun data yang ditabulasi terdiri dari data Nomor Kartu Keluarga, tanggal dikeluarkan, nama, NIK, jenis kelamin (laki-laki/perempuan), tanggal lahir, pekerjaan, agama, pendidikan, dan status (kawin/belum kawin/cerai nikah/cerai mati). Total KK yang ditabulasi dan diolah adalah $316 \mathrm{KK}$ dengan jumlah 
penduduk sebanyak 978 orang. Gambar 1 menunjukkan program Excell yang digunakan untuk pendataan. Gambar 2 hingga Gambar 6 menunjukkan hasil olah data kependudukan. Selanjutnya tampak hasil olah data kemudian dibingkai dan dipajang di rumah kepala dusun Mangiran yang difungsikan sebagai kantor.

Administrasi kependudukan adalah rangkaian kegiatan penataan dan penertiban dalam penerbitan dokumen, dan data kependudukan melalui pendaftaran penduduk, pencatatan sipil dan pengelolaan informasi serta pendayagunaan hasilnya untuk pelayanan publik dan pembangunan. Sistem pengelolaan dokumen kependudukan yang kurang baik menjadi permasalahan utama tidak tersusunnya administrasi di Dusun Mangiran. Pengelolaan penyimpanan dokumen yang kurang baik, tidak adanya kesadaran masyarakat untuk melaporkan perpindahan, kelahiran dan kematian juga merupakan masalah yang berdampak langsung dengan administrasi kependudukan. Padahal sebenarnya administrasi kependudukan merupakan suatu hal yang sangat urgen di dalam kehidupan masyarakat saat ini. Kependudukan selalu bersentuhan dengan setiap aktivitas seseorang diantaranya adalah saat pemilu legislatif, pemilihan presiden, pilkada, mengurus surat-surat kendaraan, mengurus surat-surat tanah, dan lain sebagainya. Apabila seseorang akan berdomisili pada suatu wilayah maka seseorang tersebut harus memiliki tanda domisili yang dibuktikan dengan Kartu Tanda Penduduk (KTP). Jika masalah ini terus berlanjut akan sulit sekali ditemukan data kependudukan yang valid dan hal ini tentu saja akan menyulitkan peangkat dusun/desa dalam memperoleh data.

Selain data kependudukan yang dibingkai, setiap RT diberi CD data kependudukan yang berisi data penduduk format excel yang dapat direvisi jika ada penambahan, pengurangan, atau perubahan data kependudukan.
Gambar 1. Proses Plah Data kependudukan

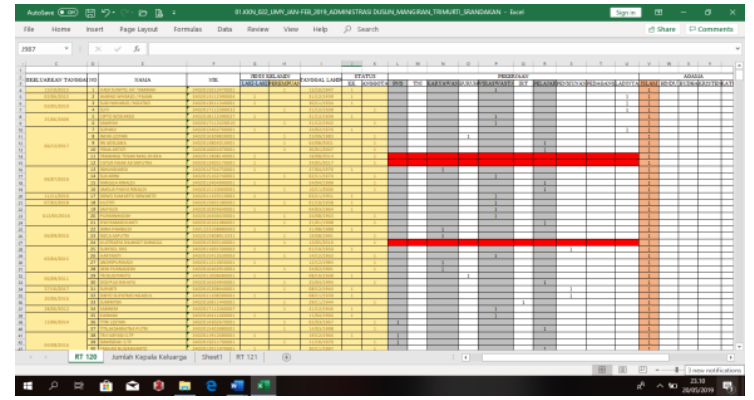

Gambar 2. Persentase Jumlah Keluarga Kepala Keluarga, dan Anggota Keluarga.

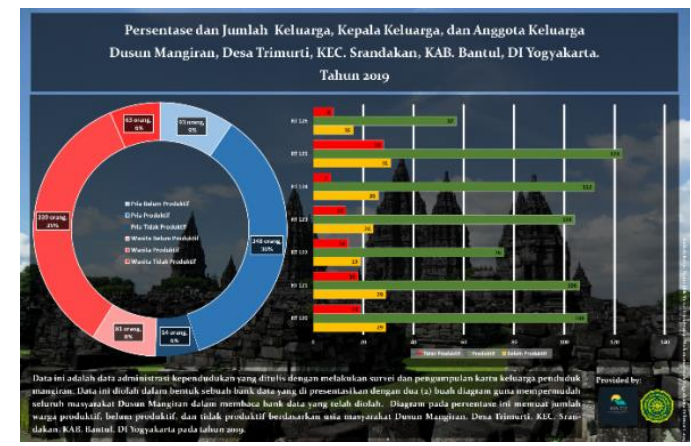

Gambar 3. Persentase dan Jumlah Rentang Umur Penduduk.

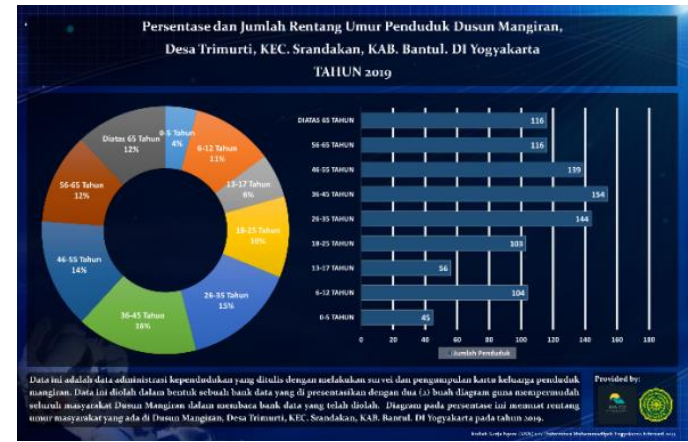

Gambar 4. Persentase dan Jumlah Penduduk Berdasarkan Jenis Kelamin.

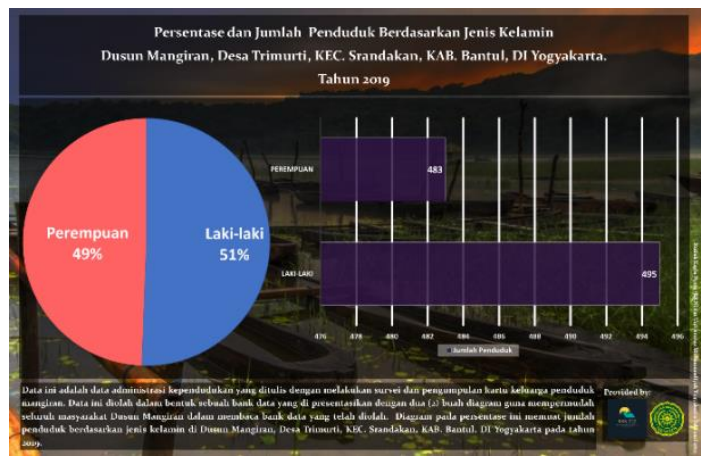

Gambar 5. Persentase dan jumlah penduduk tiap RT. 


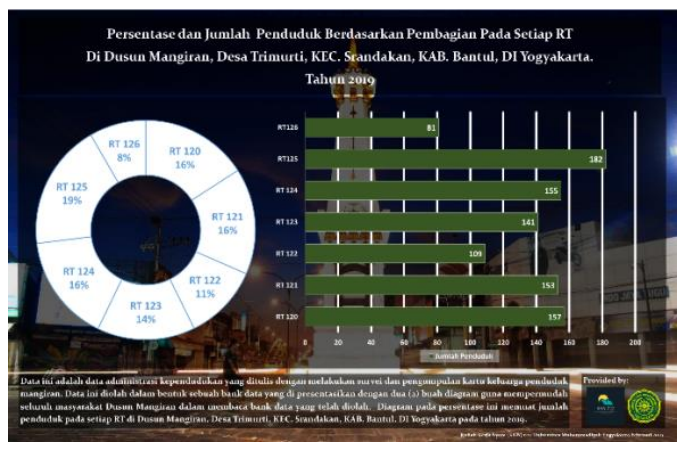

Gambar 6. Persentase dan Jumlah Keluarga

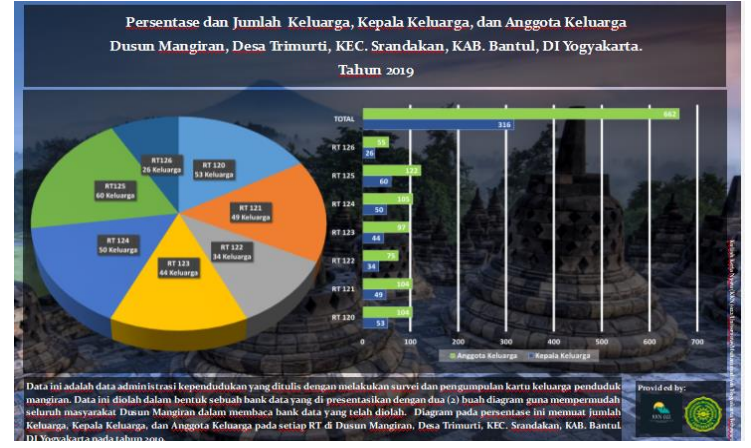

\section{Pengemasan dan Pemasaran Kethak}

Kethak merupakan hasil olahan dari Rumah produksi Kethak yang memproduksi minyak goreng dengan bahan utama kelapa. Kethuk merupakan salah satu makanan tradisional yang ada di Dusun Mangiran yang terbuat dari ampas kelapa dicampur dengan gula merah. Selama ini kemasan kethak belum menarik dan juga pemasarannya belum meluas,karena keterbatasan modal. Sehingga belum bisa menjual produk sendiri dan bergantung kepada perusahaan pemesan, padahal sebenarnya jika produk dijual sendiri akan lebih menguntungkan, maka dari itu program KKN PPM adalah membantu merancang pengemasan dan pemasaran guna meningkatkan nilai jual makanan kethak tersebut. Kegiatan yang dilakukan adalah membuat merk "Kethak Sulastri", membuat stiker, untuk kemudian membuat kemasan sebagaimana yang tampak pada Gambar 7. Selain membuat merek dan kemasan, dirancang pula papan nama "Ketak Sulastri" sebagaimana yang tampak pada Gambar 8, kemudian papan nama tersebut dipasang di rumah produksi "Kethak Sulastri". Kethak yang sudah dikemas kemudian dipasarkan dengan cara dititipkan ke beberapa toko oleh-oleh. Untuk itu sangat dibutuhkan pengarahan dan penjelasan mengenai pengembangan desain produk yang dapat meningkatkan nilai jual. Selain itu juga memahami selera pasar dan mengetahui strategi pemasaran dan pembelajaran Teknologi pemasaran khususnya secara online (Nuwa et al., 2017). Menurut Tjiptono (1999:106) dalam Setyawan dan Sari (2016) menyatakan bahwa pemberian kemasan pada produk memiliki beberapa tujuan, yaitu pelindung isi (protection); (b) memberikan kemudahan dalam penggunaan (operation); (c) bermanfaat dalam pemakaian ulang (reusable); (d) memberi daya tarik (promotion) berupa aspek artistik, warna, bentuk, dan desain; (e) sebagai salah satu identitas produk (image); (f) memudahkan proses distribusi (shipping); dan (g) dapat memberikan informasi (labelling) yang menyangkut isi, pemakaian, kualitas, dan sebagai cermin dalam inovasi produk yang berkaitan dengan kemajuan teknologi dan daur ulang.

Gambar 7. Kemasan Produk Kethak.

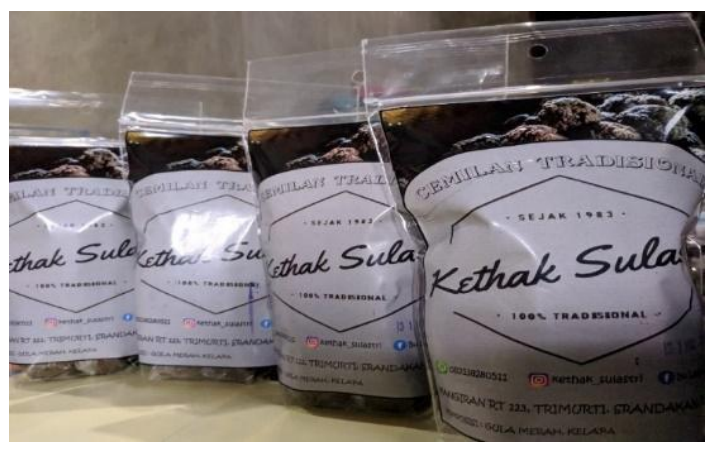

Gambar 8. Papan Nama Kethak Sulastri.

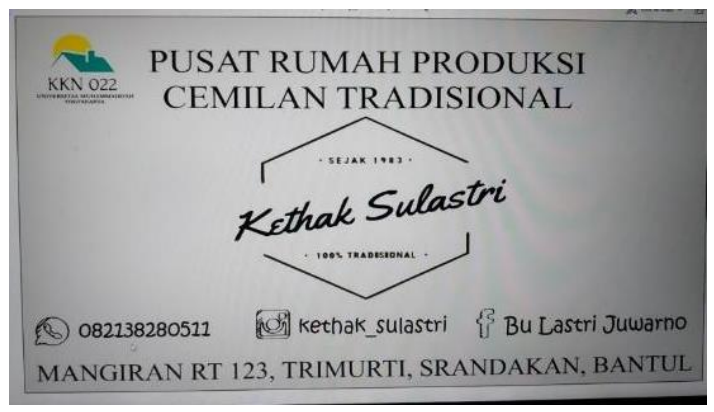




\section{Program Bantu Bimbingan Belajar Anak}

Belajar adalah kegiatan yang menunjang tingkat intelektualitas seorang manusia. Proses belajar adalah hal sederhana yang harus dimulai sejak dini. Bimbingan belajar adalah hal yang sangat penting dilakukan dalam kegiatan Kuliah Kerja Nyata. Kegiatan ini bertujuan untuk membantu anak-anak dusun Mangiran dalam proses belajar dan menyerap pelajaran sekolah. Dalam kegiatan ini mahasiswa berperan aktif dalam mewujudkan tujuan Indonesia yaitu mencerdaskan kehidupan bangsa. Kegiatan ini dilaksanakan pada 14 Januari hingga akhir masa KKN setiap jam 19.00-21.30 WIB yang diisi dan difasilitasi oleh mahasiswa KKN 022 UMY. Kegiatan ini bertujuan untuk mencerdaskan generasi muda bangsa Indonesia dan sebagai sarana pendekatan kepada masyarakat.

Bimbingan belajar merupakan salah satu bentuk program edukasi yang dilakukan, banyak kendala yang dialami yaitu banyaknya anak-anak yang belum menguasai materi yang ditugaskan dan ada beberapa anak yang datang membawa tugas tidak mengerjakan tetapi bermain yang dapat mengganggu konsentrasi anak-anak yang lain. Maka dari itu KKN UMY 2019 membuat program ini bertujuan untuk membimbing dan memberikan pengetahuan kepada anak-anak di Dusun Mangiran.

\section{Kerja Bakti Masid}

Kerja bakti masjid adalah program yang bertujuan meningkatkan semangat religiusitas masyarakat dusun mangiran. Masjid adalah infrastruktur penting dalam bidang religius masyarakat Dusun Mangiran. Program kerja ini dilaksanakan menurut standar kebersihan dalam menyelenggarakan sholat Jum'at. Program kerja ini dilaksanakan pada setiap Jum'at pukul 08.00-11.00 WIB. Kegiatan ini sebagai salah satu program bantu yang bertujuan untuk menjaga dan meningkatkan religiusitas masyarakat dusun Mangiran dan sebagai sarana pendekatan kepada masyarakat.

\section{Membantu proses belajar mengajar (KBM) Taman Pendidikan Al-Qur'an}

Taman Pendidikan Al-Qur'an (TPA) adalah kegiatan yang penting dalam membangun sikap, kesadaran, dan kecintaan anak-anak dusun Mangiran terhadap agama Islam. Kegiatan ini biasanya dilaksanakan oleh Remaja Masjid dalam menjalankan proses belajar mengajar. Mahasiswa KKN 022 UMY berperan sebagai tenaga pengajar sementara yang memiliki kewajiban dan tugas membantu mengajar anak-anak dusun

Mangiran membaca Al-Qur'an dan memahami nilai-nilai Islam. Kegiatan ini dilaksanakan pada setiap hari Senin, Rabu, dan Jum'at pukul 18.00-20.00 WIB.

TPA merupakan salah satu bentuk program keagamaan yang dilakukan, namun pada kenyataannya pendidik TPA di dusun Mangiran tidak sebanding dengan jumlah murid yang ada atau setara dengan 1 banding 10. Sehingga dengan terbatasnya jumlah pendidik TPA maka akan mempengaruhi semangat anak-anak juga akan terkena dampaknya berupa banyaknya anak-anak yang sekedar bermain. Maka dari itu KKN UMY 2019 membuat program ini bertujuan untuk membantu pendidik yang ada di Dusun Mangiran.

\section{Membantu proses kegiatan belajar mengajar (KBM) Pendidikan Anak Usia Dini (PAUD)}

PAUD atau Pendidikan Anak Usia Dini adalah program pendidikan yang diberikan kepada anak-anak dibawah 5 tahun untuk membiarkan mereka beradaptasi dengan lingkungan sosial. Dalam program ini PAUD adalah hal yang dibutuhkan demi tumbuh kembang seorang anak. Mahasiswa berperan menjadi tenaga pengajar pembantu yang berada di PAUD dusun mangiran. Hal ini memberikan manfaat tersendiri bagi mahasiswa maupun masyarakat. Kegiatan membantu mengajar di PAUD ini dilaksanakan pada senin sampai sabtu pukul 08.30-11.00 WIB. 


\section{Aktif dalam kegiatan sosial masyarakat}

Kegiatan sosial masyarakat adalah kegiatan yang dilakukan oleh mahasiswa KKN 022 UMY dalam menunjang hubungan sosial di masyarakat. Hubungan sosial ini diimplementasikan dan distimulasikan dengan melakukan sosialisasi. Sosialisasi kepada masyarakat hanya dapat dilakukan melalui kegiatan sosial di masyarakat. Kegiatan ini terdiri dari gotong-royong, rapat dengan kelompok masyarakat, membantu menyelenggarakan acara-acara yang di buat dengan masyarakat, dan berpartisipasi denggan setiap kegiatan masyarakat dusun Mangiran.

\section{Pengajian}

Pengajian adalah program yang bertujuan meningkatkan nilai keislaman masyarakat dusun Mangiran. Pengajian juga merupakan kegiatan rutin yang kerap dilaksanakan pada setiap minggunya. Selain meningkatkan nilai religius, kegiatan ini juga dimanfaatkan sebagai sarana silaturahmi antar masyarakat dusun Mangiran. Kegiatan ini dibagi dalam dua kategori yaitu Pengajian Bapak-bapak yang pesertanya adalah laki-laki yang dilaksanakan pada setiap Kamis pukul 20.00-23.00 WIB dan Pengajian Ibu-ibu yang pesertanya adalah perempuan yang dilaksanakan pada setiap Jum'at pukul 20.00-22.00 WIB. Lokasi dilaksanakannya kegiatan tersebut tidak tetap karena dilakukan secara bergantian di rumah warga dusun Mangiran.

\section{Perpisahan}

Perpisahan adalah kegiatan salam pelepasan antara mahasiswa KKN 022 UMY dan masyarakat dusun Mangiran. Kegiatan ini bertujuan untuk memberikan salam perpisahan dan silaturahmi terakhir sebelum mahasiswa KKN 022 UMY ditarik kembali ke kampus. Dalam acara ini diikuti dengan presentasi hasil program mahasiswa KKN 022 UMY dan pemberian kenangkenangan atau cinderamata kepada tokoh masyarakat dusun Mangiran sebagai perwakilan dari masyarakat. Acara ini diselenggarakan oleh mahasiswa KKN 022 UMY pada hari Rabu, 13 Februari 2019.

\section{KESIMPULAN}

Hasil dari kegiatan utama adalah adanya administrasi dusun berupa soft file yang diberikan kepada Kepala Dusun dalam bentuk CD yang bisa diedit setiap saat ketika ada perubahan data dan informasi berupa gambar terbingkai. Kegiatan pengabdian pada masyarakat yang mengambil tema pembentukan administrasi dusun berbasis Microsoft Excel ini sangat berdaya guna untuk menunjang perangkat desa tersebut dalam membuat laporan administrasi kependudukan dan laporan lainnya sebagai bentuk pelayanan kepada masyarakat agar lebih efektif dan efisien sehingga roda pemerintahan desa dapat berjalan dengan baik. Untuk produk kethak, telah tersedia kethak yang bermerk dan terkemas baik, serta adanya plang papan nama industry kethak. Kegiatan pendamping juga telah berjalan dengan baik.

\section{UCAPAN TERIMAKASIH}

Kegiatan ini terwujud atas pendanaan Berdasarkan Keputusan Kepala Lembaga Penelitian, Publikasi, dan Pengabdian Universitas Muhammadiyah Yogyakarta Nomor: 2816/SK-LP3M/I/2019 Tentang Penerima Hibah Pengabdian Masyarakat Batch 1 Program Peningkatan Tri Dharma Perguruan Tinggi Universitas Muhammadiyah Yogyakarta Tahun Akademik 2018/2019.

\section{DAFTAR PUSTAKA}

Maimunah, S., Fahruni, \& Hanafi, N. (2018). Peningkatan Ekonomi Masyarakat Sekitar Kawasan Hutan Gambut Dengan Pemanfaatan Purun. Jurnal PengabdianMu, 3, 20-26. 
Mardiah, Suprayatmi, M., Gemina, D., \& Rahayu, A. (2015). Strategi Meningkatkan Daya Beli Masyarakat Melalui IPTEK Bagi Masyarakat Petani Rosela. Qardhul Hasan: Media Pengabdian Kepada Masyarakat, 1(1), 11-32.

Nuwa, N., Putir, P. E., \& Pisi, B. (2017). Pendampingan Pengembangan Desain dan Pemasaran On-Line Produk Perajin Anyaman Rotan di Wilayah Kecamatan Jekan Raya. PengabdianMu: Jurnal Ilmiah Pengabdian Kepada Masyarakat, 2(2), 93-103.

Paramita, M., Muhlisin, S., \& Palawa, I. (2018). Peningkatan Ekonomi Masyarakat Melalui Pemanfaatan
Sumber Daya Lokal. Qardhul Hasan: Media Pengabdian Kepada Masyarakat, 4(1), 19-30.

Sesrita, A., Anwar, E., \& Fadillah, A. (2017). Improving Quality Of Education And Empowerment Of Rural. Qardhul Hasan: Media Pengabdian Kepada Masyarakat, 3(1), 15-26.

Setyawan, F., \& Sari, P. N. (2016). Labelling Kemasan Sebagai Upaya Pengembangan Pemasaran Agroindustri Emping Jagung di Desa Tirtomulyo, Kretek, Bantul. Jurnal Pengabdian Kepada Masyarakat (Indonesian Journal of Community Engagement), 1(2), 231-238. 